Revista Brasil. Bot., V.32, n.2, p.253-270, abr.-jun. 2009

\title{
Cryptoglena, Monomorphina and Phacus (Euglenophyceae) of a reservoir in the State of Rio Grande do Sul, southern Brazil
}

\author{
SANDRA MARIA ALVES-DA-SILVA ${ }^{1}$ and CARLOS E. DE M. BICUDO ${ }^{2,3}$
}

(received: August 2, 2007; accepted: February 12, 2009)

\begin{abstract}
Cryptoglena, Monomorphina and Phacus (Euglenophyceae) of a reservoir in the State of Rio Grande do Sul, southern Brazil). Taxonomic survey of representatives of genera Cryptoglena Ehrenberg emend. Kosmala \& Zakryś, Monomorphina Mereschkowsky emend. Kosmala \& Zakryś and Phacus Dujardin (Euglenaceae, Euglenophyceae) of a reservoir in the municipality of Triunfo (3002'15' S, $51^{\circ} 13^{\prime} 13^{\prime}$ ' W), state of Rio Grande do Sul, southern Brazil. Samplings were performed at two stations during 14 consecutive months, from February 1995 to March 1996. Sixteen taxa including nine species, three varieties that are not typical of their respective species and one taxonomic forma also not typical of Phacus, two species of Monomorphina and one of Cryptoglena were identified. Phacus pseudobicarinatus is described as a new species. Phacus longicauda (Ehrenberg) Dujardin var. longicauda, P. longicauda (Ehrenberg) Dujardin var. tortus Lemmermann, P. orbicularis Hübner, P. pleuronectes (O.F. Müller) Dujardin and P. pseudobicarinatus nov. sp. were the best represented taxa geographycally, occurring in more than 55\% of samples studied. Phacus longicauda var. longicauda and $P$. longicauda var. tortus were characteristic by their wide tolerance to the following environmental variables: $\mathrm{pH}$, water temperature, organic matter concentration, total phosphorus and the nitrogen series (nitrite, nitrate, ammonium and total nitrogen). Phacus undulatus f. major is cited for the first time for Brazil.
\end{abstract}

Key words - Brazil, Euglenophyceae, taxonomic survey, Rio Grande do Sul State

RESUMO - (Cryptoglena, Monomorphina e Phacus (Euglenophyceae) de um reservatório no Estado do Rio Grande do Sul, sul do Brasil). Estudo taxonômico dos gêneros Cryptoglena Ehrenberg emend. Kosmala \& Zakryś, Monomorphina Mereschkowsky emend. Kosmala \& Zakryś and Phacus Dujardin (Euglenaceae, Euglenophyceae) em um reservatório raso no Município de Triunfo (3002’15” S, 51¹3'13” W), Estado do Rio Grande do Sul, sul do Brasil. As amostragens foram realizadas em duas estações de coleta durante 14 meses consecutivos, de fevereiro de 1995 a março de 1996. O estudo resultou na identificação de 16 táxons assim distribuídos: nove espécies, três variedades que não são as típicas de suas respectivas espécies e uma forma também não típica, porém, de sua respectiva variedade do gênero Phacus, duas espécies de Monomorphina e uma de Cryptoglena. Phacus pseudobicarinatus é descrito como uma nova espécie. Phacus longicauda (Ehrenberg) Dujardin var. longicauda, P. longicauda (Ehrenberg) Dujardin var. tortus Lemmermann, P. orbicularis Hübner, P. pleuronectes (O.F. Müller) Dujardin e P. pseudobicarinatus nov. sp. são os táxons melhor representados geograficamente na área de estudo por estarem presentes em mais de 55\% das amostras analisadas. Phacus longicauda var. longicauda e P. longicauda var. tortus foram característicos pelo seu amplo espectro de tolerância às seguintes variáveis ambientais: pH, temperatura da água, matéria orgânica, fósforo total e a série de nitrogênio (nitrato, nitrito, amônio e nitrogênio total). Phacus undulatus f. major tem sua ocorrência referida pela primeira vez para o Brasil.

Palavras-chave - Brasil, estudo taxonômico, Euglenophyceae, Rio Grande do Sul

\section{Introduction}

Euglenophytes are free-swimming algal flagellates found in a variety of freshwater and marine environments. Despite the fact that they are of common occurrence, its taxonomy still is problematic.

Several papers were published during the last two decades based on molecular biology attempting to elucidate taxonomic and phylogenetic questions among

\footnotetext{
1. Museu de Ciências Naturais, Fundação Zoobotânica do Rio Grande do Sul, Caixa Postal 1188, 90690-000 Porto Alegre, RS, Brazil.

2. Instituto de Botânica, Caixa Postal 3005, 01061-970 São Paulo, SP, Brazil.

3. Corresponding author: cbicudo@terra.com.br
}

the Euglenophyceae. Some of these (Linton et al. 1999, 2000, Preisfeld et al. 2000, 2001, Leander et al. 2001, Busse \& Preisfeld 2002, 2003, Marin et al. 2003) dealt with the pigmented Euglenophyceae. Marin et al. (2003) reintroduced Mereschkowsky's (1877) genus Monomorphina by transferring representatives of Pochmann's (1942) sect. Pleuraspis. Phacus agilis Skuja var. agilis was also transferred to Cryptoglena under the combination C. skujae. Subsenquently, Kosmala and Zakryś in Kosmala et al. (2007b) emended the genus description.

Present work is the taxonomic survey of representatives of genera Cryptoglena, Monomorphina and Phacus in the contention basin n. 7, a reservoir located in a Biological 
Reserve under jurisdiction of the petrochemical company Pólo Petroquímico do Sul in the municipality of Triunfo, state of Rio Grande do Sul. It aimed at broadening the knowledge on the taxonomy and geographical distribution of these algae, as well as at supplying information on the environmental conditions in which the material studied was collected in an attempt to subsidize ecological studies being carried out in the area.

Knowledge of the algae of the present study area is restricted to two publications, Torgan et al. (1979) and Alves-da-Silva \& Laitano (1994), from which the former refers to representatives of the phytoplankton in general, including euglenophytes, and the latter to 46 specific and infraspecific taxa of pigmented Euglenaceae. Based on samples collected from a wetland (Banhado do Jacaré) near the contention basin n. 7, Alves-da-Silva \& Laitano (1994) identified 15 taxa of Phacus, from which five $[P$. acuminatus Stokes var. variabilis (Lemmermann) Pochman, $P$. contortus Bourrelly var. contortus, $P$. curvicauda Swirenko, $P$. orbicularis Hübner and $P$. pleuronectes (O.F. Müller) Dujardin] and Cryptoglena skujae Marin \& Melkonian emend. Kosmala \& Zakryś (= P. agilis Skuja var. agilis) as well as Monomorphina aenigmatica (Drezepolski) Nudelman \& Triemer (= as Phacus aenigmaticus Drezepolski) are common to both systems.

\section{Material and methods}

Contention basin n. $7\left(30^{\circ} 02^{\prime} 15^{\prime \prime} \mathrm{S}, 51^{\circ} 13^{\prime} 13^{\prime \prime} \mathrm{W}\right)$ was built for retention and accumulation of rain water (figure 1). It is located in a Biological Reserve under jurisdiction of the petrochemical company Pólo Petroquímico do Sul and is a refuge site for the remaining biota after the 1978 installation of the petrochemical complex in the municipality of Triunfo, Rio Grande do Sul State, southern Brazil. Basin n. 7 has the surface of approximately 15 ha and the maximum depth of $2 \mathrm{~m}$ during the rainy season. Climate of the study area is subtropical.

Samples for the physical and chemical analyses of water as well as those for biological material study were gathered monthly, from February 1995 to March 1996, in two collecting stations. Station 1 was located in the central-most part of the basin and station 2 at the basin margin. Samples were gathered from the subsurface $(20-30 \mathrm{~cm}$ depth) of the water column of reservoir by using a $25 \mu \mathrm{m}$ mesh plankton net. Immediately after collection, samples were subdivided into two parts. One of them was fixed in the field with $4 \%$ formaldehyde, whereas the other one was kept alive for observation of certain morphological features that demand living material for a proper exam. A Dialux Leitz optical microscope with a micrometer eyepiece and camera lucida was used for the study of material.
Physical and chemical analyses of the water from the reservoir were processed according to the following methods: water temperature directly with a chemical thermometer; water transparency directly with a Secchi disk; dissolved oxygen concentration by the Winkler method modified; total phosphorus (TP), ortophosphate $\left(\mathrm{PO}_{4}\right)$, ammonium $\left(\mathrm{NH}_{4}\right)$, nitrite $\left(\mathrm{NO}_{2}\right)$ and nitrate $\left(\mathrm{NO}_{3}\right)$ by the methods in Golterman et al. (1978); free $\mathrm{CO}_{2}$ concentration from the total alkalinity values; $\mathrm{pH}$ directly with a digital $\mathrm{pHmeter}$ Digimed, model DMPH-P; water electric conductivity directly with a field conductivimeter Digimed, model CD-2P; total alkalinity by potentiometric titration; organic matter using the potassium permanganate method (consumed oxygen); and total nitrogen
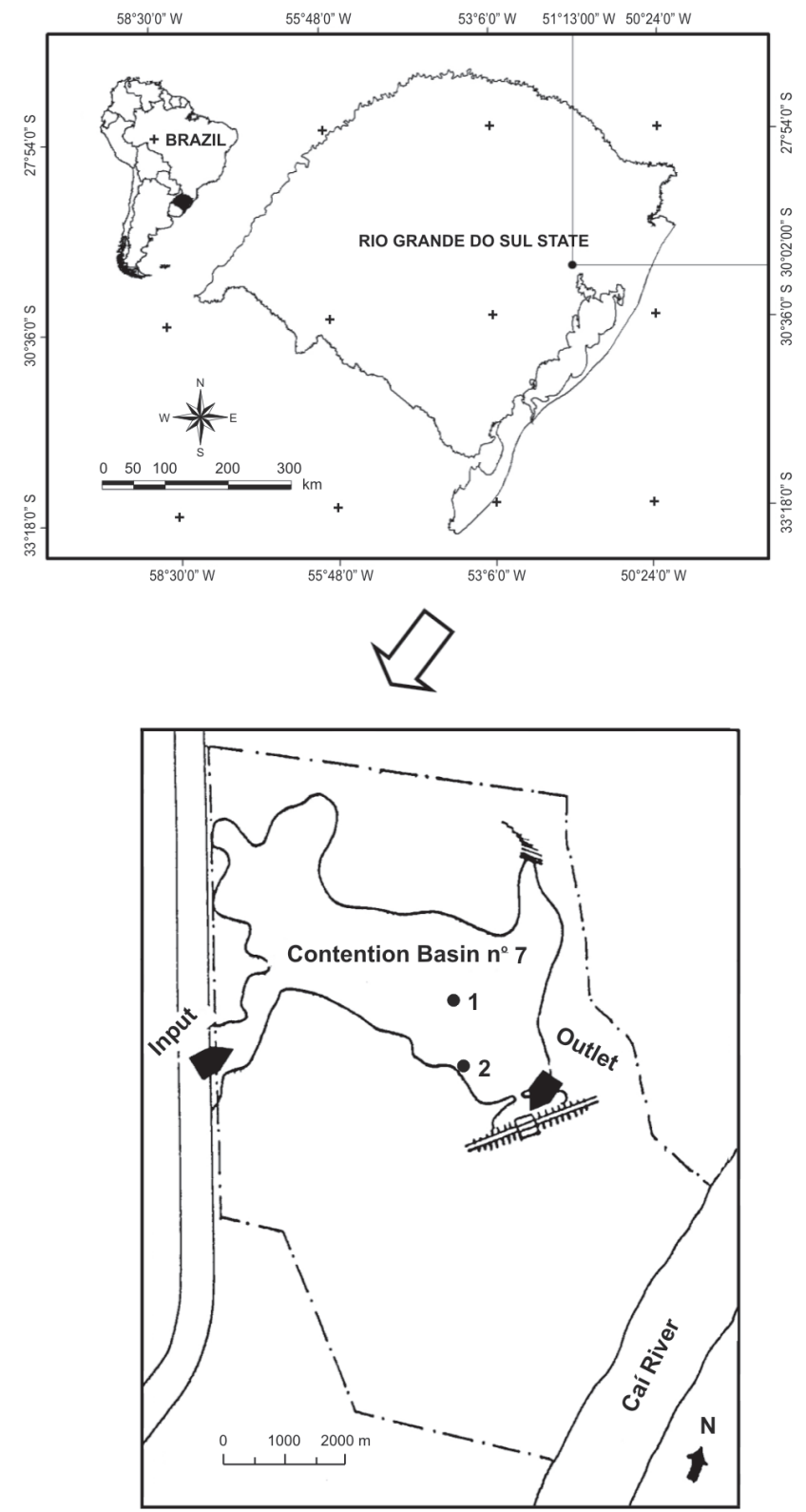

Figure 1. Location of sampling stations in the contention basin n. 7, municipality of Triunfo, state of Rio Grande do Sul, Brazil. 
(TN) concentration by spectrophotometry, according to Mackereth et al. (1978).

For identification of Monomorphina and Cryptoglena taxa, works by Marin et al. (2003), Nudelman et al. (2006) and Kosmala et al. (2007b) were adopted. For identification of Phacus species and infraspecific taxa, basic works such as Huber-Pestalozzi (1955), Kosmala et al. (2007a), Németh (1980), Pochmann (1942), Starmach (1983), Tell \& Conforti (1986), Weik (1967) and Wołowski (1998) were used, as well as several recent floristic works.
Table 1 shows the variation range of abiotic data at sampling stations 1 and 2, whereas table 2 includes Cryptoglena, Monomorphina and Phacus species, varieties, and taxonomic formae identified for contention basin n. 7 during the study period.

All samples containing representatives of Cryptoglena, Monomorphina and Phacus were deposited in the Herbarium Prof. Dr. Alarich R.H. Schultz (HAS) of the Museum of Natural Sciences of the Fundação Zoobotânica of Rio Grande do Sul, Rio Grande do Sul State, southern Brazil.

Table 1. Variation range of abiotic data $(n=28)$ at sampling stations 1 and 2 , contention basin $\mathrm{n}$. 7 , during the period from February 1995 to March 1996.

\begin{tabular}{|c|c|c|c|c|c|c|}
\hline Taxa / Environmental variables & $\mathrm{pH}$ & $\begin{array}{l}\text { Water temperature } \\
\qquad\left({ }^{\circ} \mathrm{C}\right)\end{array}$ & $\begin{array}{c}\mathrm{NH}_{4} \\
\left(\mu \mathrm{g} \mathrm{L}^{-1}\right)\end{array}$ & $\begin{array}{c}\mathrm{NO}_{2} \\
\left(\mu \mathrm{g} \mathrm{L}^{-1}\right)\end{array}$ & $\begin{array}{c}\mathrm{NO}_{3} \\
\left(\mu \mathrm{g} \mathrm{L}^{-1}\right)\end{array}$ & $\begin{array}{l}\text { Total N } \\
\left(\mu g L^{-1}\right)\end{array}$ \\
\hline Cryptoglena skujae & $5.5-8.0$ & $21-26$ & $15-80$ & $1.8-9$ & $35-43$ & $52-161$ \\
\hline Monomorphina nordstedtii & 6.8 & 20 & 100 & 8 & 28 & 142 \\
\hline M. pyrum & $5.5-8.0$ & $17-26$ & $28-130$ & $4.0-42$ & $28-222$ & $52-265$ \\
\hline Phacus acuminatus var. acuminatus & $5.7-7.2$ & $21-26$ & $15-100$ & $4.0-9.0$ & $28-65$ & $52-142$ \\
\hline P. acuminatus var. variabilis & $5.5-8.0$ & $13-26$ & $15-226$ & $1.8-42$ & $3.7-222$ & $52-270$ \\
\hline P. contortus & $5.7-7.5$ & $11-26$ & $15-131$ & $4.0-11$ & $30-168$ & $57-182$ \\
\hline P. curvicauda & $5.5-7.7$ & $13-32$ & $15-130$ & $2.0-42$ & $28-222$ & $57-265$ \\
\hline P. hamatus & $6.6-7.4$ & $13-21$ & $100-126$ & $8.0-42$ & $28-222$ & $114-265$ \\
\hline P. longicauda var. longicauda & $5.5-7.7$ & $13-31$ & $15-130$ & $2.0-42$ & $28-222$ & $57-265$ \\
\hline P. longicauda var. tortus & $5.5-7.7$ & $11-31$ & $15-265$ & $1.8-41$ & $30-205$ & $57-242$ \\
\hline P. orbicularis & $6.6-7.7$ & $11-31$ & $28-247$ & $2.0-42$ & $28-222$ & $70-265$ \\
\hline P. platalea var. major & $5.5-7.3$ & $17-25$ & $15-126$ & $7.0-42$ & $42-222$ & $60-265$ \\
\hline P. pleuronectes & $5.5-8.0$ & $11-31$ & $15-226$ & $1.8-42$ & $28-222$ & $52-270$ \\
\hline P. polytrophos & $6.8-6.9$ & $20-25$ & $28-100$ & $4.0-8$ & $28-37$ & $114-142$ \\
\hline P. pseudobicarinatus & $5.5-8.0$ & $13-26$ & $15-226$ & $1.8-42$ & $3.6-222$ & $52-270$ \\
\hline P. undulatus f. major & $6.8-7.5$ & $11-21$ & $100-131$ & $8.0-11$ & $30-168$ & $114-265$ \\
\hline Taxa / Environmental variables & $\begin{array}{l}\text { Total P } \\
\left(\mu \mathrm{g} \mathrm{L}^{-1}\right)\end{array}$ & $\begin{array}{l}\text { Organic matter } \\
\quad\left(\mathrm{mg} \mathrm{L}^{-1}\right)\end{array}$ & $\begin{array}{c}\text { D.O. } \\
\left(\mathrm{mg} \mathrm{L}^{-1}\right)\end{array}$ & $\begin{array}{l}\text { Conductivity } \\
\left(\mu \mathrm{g} \mathrm{L}^{-1}\right)\end{array}$ & $\begin{array}{l}\text { Alkalinity } \\
\left(\mathrm{mg} \mathrm{L}^{-1}\right)\end{array}$ & $\begin{array}{c}\mathrm{PO}_{4} \\
\left(\mu \mathrm{g} \mathrm{L}^{-1}\right)\end{array}$ \\
\hline Cryptoglena skujae & $23-66$ & $1.8-5.8$ & $7.0-8.3$ & $110-170$ & $18-26$ & $<1.3-32$ \\
\hline Monomorphina nordstedtii & 46 & 2.1 & 6.8 & 110 & 20 & 5 \\
\hline M. pyrum & $21-66$ & $1.3-5.8$ & $6.5-8.3$ & $90-170$ & $19-26$ & $<1.3-34$ \\
\hline Phacus acuminatus var. acuminatus & $17-330$ & $1.0-6.3$ & $6.8-7.5$ & 110 & $19-20$ & $<1.3-34$ \\
\hline P. acuminatus var. variabilis & $23-330$ & $1.8-4.3$ & $6.8-7.5$ & $110-140$ & $16-38$ & $<1.3-34$ \\
\hline P. contortus & $40-46$ & $1.2-3$ & $6.9-7.5$ & $70-110$ & $16-26$ & $<1.3-34$ \\
\hline P. curvicauda & $10.4-46$ & $0.7-3.0$ & $6.5-8.4$ & $70-110$ & $16-27$ & $<1.3-34$ \\
\hline P. hamatus & $28-46$ & $1.0-2.1$ & $6.5-7.0$ & $70-110$ & $19-27$ & $<1.3-5.0$ \\
\hline P. longicauda var. longicauda & $12.4-46$ & $0.7-3.0$ & $6.5-8.4$ & $70-170$ & $18-42$ & $<1.3-34$ \\
\hline P. longicauda var. tortus & $12.4-650$ & $0.7-6.3$ & $6.3-8.4$ & $70-180$ & $16-42$ & $<1.3-34$ \\
\hline P. orbicularis & $12.4-46$ & $0.7-2.1$ & $6.7-8.4$ & $70-180$ & $19-42$ & $<1.3-5.0$ \\
\hline P. platalea var. major & $17-38$ & $1.0-3$ & $6.5-8.4$ & $100-120$ & $18-26$ & $<1.3-32$ \\
\hline P. pleuronectes & $12.4-145$ & $0.7-2.1$ & $6.8-8.4$ & $70-120$ & $18-27$ & $<1.3-32$ \\
\hline P. polytrophos & $46-50$ & $1.8-2.6$ & $6.8-7.5$ & 110 & $19-20$ & $<1.3-5.0$ \\
\hline P. pseudobicarinatus & $17-330$ & $1.0-6.3$ & $6.5-8.4$ & $70-170$ & $16-27$ & $<1.3-34$ \\
\hline P. undulatus f. major & $45-46$ & $1.0-1.8$ & $6.9-7$ & $70-110$ & $19-26$ & $<1.3-3$ \\
\hline
\end{tabular}

$<1.3=$ not detected 
Table 2. Presence of representatives of Cryptoglena, Monomorphina and Phacus in the contention basin n. 7, sampling stations 1 and 2, during the period from February 1995 to March 1996.

\begin{tabular}{|c|c|c|c|c|c|c|c|c|c|c|c|c|c|c|}
\hline & $\mathrm{Feb}$ & Mar & Apr & May & Jun & Jul & Aug & Sep & Oct & Nov & Dec & Jan & Feb & Mar \\
\hline & \multicolumn{11}{|c|}{95} & \multicolumn{3}{|c|}{96} \\
\hline \multicolumn{15}{|l|}{ Station 1} \\
\hline Cryptoglena skujae & $\mathrm{X}$ & $\mathrm{X}$ & - & $\mathrm{X}$ & - & - & - & - & - & - & - & - & - & - \\
\hline Monomorphina nordstedtii & - & - & $\mathrm{X}$ & - & - & - & - & - & - & - & - & - & - & - \\
\hline M. pyrum & $\mathrm{X}$ & $\mathrm{X}$ & $\mathrm{X}$ & $\mathrm{X}$ & - & $\mathrm{X}$ & $\mathrm{X}$ & - & - & - & - & - & - & - \\
\hline $\begin{array}{l}\text { Phacus acuminatus var. } \\
\text { acuminatus }\end{array}$ & - & $X$ & $\mathrm{X}$ & $\mathrm{X}$ & - & - & - & - & - & - & - & - & $\mathrm{X}$ & - \\
\hline P. acuminatus var. variabilis & - & - & $\mathrm{X}$ & $\mathrm{X}$ & - & - & - & - & - & - & - & - & - & - \\
\hline P. contortus & $\mathrm{X}$ & $\mathrm{X}$ & - & - & - & - & $\mathrm{X}$ & - & - & - & - & - & - & - \\
\hline P. curvicauda & $\mathrm{X}$ & $\mathrm{X}$ & $\mathrm{X}$ & $X$ & $\mathrm{X}$ & $X$ & $\mathrm{X}$ & - & - & $\mathrm{X}$ & - & - & - & - \\
\hline P. hamatus & - & - & $\mathrm{X}$ & - & - & $\mathrm{X}$ & $\mathrm{X}$ & - & - & - & - & - & - & - \\
\hline P. longicauda var. longicauda & $\mathrm{X}$ & $X$ & $\mathrm{X}$ & $X$ & $\mathrm{X}$ & $\mathrm{X}$ & $\mathrm{X}$ & $\mathrm{X}$ & $X$ & $\mathrm{X}$ & $\mathrm{X}$ & $\mathrm{X}$ & $\mathrm{X}$ & $X$ \\
\hline P. longicauda var. tortus & $\mathrm{X}$ & $X$ & $\mathrm{X}$ & - & $\mathrm{X}$ & $\mathrm{X}$ & $\mathrm{X}$ & $\mathrm{X}$ & - & $\mathrm{X}$ & $\mathrm{X}$ & - & $\mathrm{X}$ & $X$ \\
\hline P. orbicularis & - & $X$ & $\mathrm{X}$ & - & $\mathrm{X}$ & $\mathrm{X}$ & $\mathrm{X}$ & $\mathrm{X}$ & $X$ & $\mathrm{X}$ & $\mathrm{X}$ & $\mathrm{X}$ & - & $X$ \\
\hline P. platalea var. major & $\mathrm{X}$ & - & - & - & - & $\mathrm{X}$ & - & - & $X$ & - & - & - & - & - \\
\hline P. pleuronectes & $\mathrm{X}$ & $X$ & $\mathrm{X}$ & $X$ & $\mathrm{X}$ & $\mathrm{X}$ & $\mathrm{X}$ & - & $X$ & $\mathrm{X}$ & - & - & - & - \\
\hline P. polytrophos & - & $X$ & $\mathrm{X}$ & - & - & - & - & - & - & - & - & - & - & - \\
\hline P. pseudobicarinatus & $\mathrm{X}$ & $X$ & $\mathrm{X}$ & $X$ & $\mathrm{X}$ & $\mathrm{X}$ & $\mathrm{X}$ & - & $\mathrm{X}$ & - & $\mathrm{X}$ & - & - & - \\
\hline P. undulatus f. major & - & - & - & - & - & - & - & - & - & - & - & - & - & - \\
\hline \multicolumn{15}{|l|}{ Station 2} \\
\hline Cryptoglena skujae & $X$ & $X$ & - & - & - & - & - & - & - & - & $\mathrm{X}$ & - & - & - \\
\hline Monomorphina nordstedtii & - & - & - & - & - & - & - & - & - & - & - & - & - & - \\
\hline M. pyrum & $\mathrm{X}$ & $X$ & $X$ & $X$ & - & - & - & - & - & - & $\mathrm{X}$ & - & - & - \\
\hline $\begin{array}{l}\text { Phacus acuminatus var. } \\
\text { acuminatus }\end{array}$ & $\mathrm{X}$ & - & - & - & - & - & - & - & - & - & - & - & - & - \\
\hline P. acuminatus var. variabilis & - & - & $\mathrm{X}$ & - & - & - & - & - & - & - & $\mathrm{X}$ & - & - & - \\
\hline P. contortus & $\mathrm{X}$ & - & $\mathrm{X}$ & $\mathrm{X}$ & - & - & - & - & - & - & - & - & - & - \\
\hline P. curvicauda & $\mathrm{X}$ & - & $\mathrm{X}$ & - & $\mathrm{X}$ & - & - & - & - & - & - & - & - & - \\
\hline P. hamatus & - & - & $\mathrm{X}$ & - & - & - & - & - & - & - & - & - & - & - \\
\hline P. longicauda var. longicauda & $\mathrm{X}$ & - & $\mathrm{X}$ & $\mathrm{X}$ & $\mathrm{X}$ & $\mathrm{X}$ & $\mathrm{X}$ & $\mathrm{X}$ & $\mathrm{X}$ & $\mathrm{X}$ & $\mathrm{X}$ & $\mathrm{X}$ & $\mathrm{X}$ & - \\
\hline P. longicauda var. tortus & $\mathrm{X}$ & - & $\mathrm{X}$ & $\mathrm{X}$ & - & $\mathrm{X}$ & $\mathrm{X}$ & - & - & $X$ & $\mathrm{X}$ & $\mathrm{X}$ & $\mathrm{X}$ & $\mathrm{X}$ \\
\hline P. orbicularis & - & - & - & $\mathrm{X}$ & - & $\mathrm{X}$ & $\mathrm{X}$ & $\mathrm{X}$ & $\mathrm{X}$ & - & - & - & $\mathrm{X}$ & - \\
\hline P. platalea var. major & - & - & - & - & - & - & - & - & - & - & - & - & - & - \\
\hline P. pleuronectes & - & - & $\mathrm{X}$ & $\mathrm{X}$ & $\mathrm{X}$ & $X$ & - & $\mathrm{X}$ & $\mathrm{X}$ & - & $\mathrm{X}$ & $X$ & - & - \\
\hline P. polytrophos & - & $\mathrm{X}$ & $\mathrm{X}$ & - & - & - & - & - & - & - & - & - & - & - \\
\hline P. pseudobicarinatus & $\mathrm{X}$ & - & $X$ & $X$ & - & - & - & $\mathrm{X}$ & - & - & $X$ & $X$ & - & - \\
\hline P. undulatus f. major & - & - & $\mathrm{X}$ & - & - & $\mathrm{X}$ & - & - & - & - & - & - & - & - \\
\hline
\end{tabular}

\section{Results and discussion}

Analysis of material collected resulted in the identification of 16 taxa of genera Cryptoglena,
Monomorphina and Phacus including species and infraspecific categories, which were distributed in 12 species, three varieties that are not typical of their respective species and one taxonomic forma that is also not typical.

Key for identification of the species, varieties and taxonomic forma of Cryptoglena, Monomorphina and Phacus from contention basin n. 7:

1. Chloroplasts 2, shield-like or U-shaped

Cryptoglena skujae

2. Paramylum 2, placed between the pellicle and the chloroplast 
3. Cell broadly pear-shaped, anterior pole rounded to slightly truncate Monomorphina nordstedtii

3. Cell narrowly pear-shaped Monomorphina pyrum

2. Paramylum 2 or more, not placed between the pellicle and the chloroplast

4. Paramylum 2, oblique, cell elliptical

Phacus polytrophos

4. Paramylum more than 2, central or excentric

5. Cell oval, caudus ca. $1 \mu \mathrm{m}$ long, not misplaced from the cell longitudinal axis Phacus acuminatus var. acuminatus

5. Cell broadly elliptic to ovate, caudus misplaced from the cell longitudinal axis (curved) Phacus acuminatus var. variabilis

1. Chloroplasts numerous, disc-shaped

6. Caudus $>15 \mu \mathrm{m}$

7. Cells broadly elliptic or obovate

8. Cell obovate, longitudinal and transverse striae present Phacus longicauda var. tortus

8. Cell broadly elliptic, only longitudinal striae present Phacus longicauda var. longicauda

7. Cells ovate to broadly ovate, with marginal notches

9. Cell ovate, $110-115 \times 61.3-66.9 \mu \mathrm{m}, \mathrm{R} 1 / \mathrm{b}=1.6-1.8$; apical sulcus almost reaching the posterior pole Phacus undulatus var. major

9. Cell broadly ovate, $115.4-125 \times 78-92.5 \mu \mathrm{m}, \mathrm{R} 1 / \mathrm{b}=1.4-1.6$; apical sulcus short, not reaching the posterior pole Phacus platalea var. major

6. Caudus $<15 \mu \mathrm{m}$

10. Cell twisted

11. Cell divided into 2 equally or unequally thickened portions Phacus curvicauda

11. Cell divided into 2 twisted unequal portions, the greater one posteriorly expanded, wing-like

Phacus contortus

10. Cell not twisted

12. Longitudinal and transverse striae present

13. Cell broadly ovate, transverse optical section 3-angular, angles rounded .. Phacus orbicularis 13. Cell strongly asymmetrical, ovate, transverse optical section 3-angular, angles rounded

Phacus pseudobicarinatus

12. Longitudinal striae present, transverse ones absent

14. Cell ovate, apical view cup-shaped

Phacus hamatus

14. Cell ovate, apical view sausage-shaped

Phacus pleuronectes

Cryptoglena skujae Marin \& Melkonian emend. Kosmala \& Zakryś, J. Phycol. 43:174, 180, fig. 18. 2007.

Figures 2-5

Cell elliptic to ovate, $12-13.9 \times 9.2-10.2 \mu \mathrm{m}, \mathrm{R} \mathrm{l} / \mathrm{b}=$ 1.3-1.4.

Geographical distribution: cosmopolitan (as Phacus agilis Skuja var. agilis).

Specimens examined: HAS26680, HAS26681, HAS26685, HAS26691, HAS26692, HAS26695, HAS26696, HAS26709, HAS26710 and HAS26785.

Comments: on the basis of molecular biology, Phacus agilis Skuja var. agilis was transferred by Marin and Melkonian in Marin et al. (2003) to Cryptoglena under the combination Cryptoglena skujae. Four years later, Kosmala and Zakryśs in Kosmala et al. (2007b) emended the genus description. Cryptoglena skujae is made up of extremely motile individuals that only very seldom are observed still. Individual cell size is the smallest in the genus.

Representative individuals of this species are easily recognized by their kidney-shaped transverse optical section, the 2 chloroplasts and 2 paramylum granules per cell, both shield-like and laterally located in the cell, and by the pellicle striae spiraled to the left.

Material presently examined fully agreed with that used for the original description of $P$. agilis. A few individuals were comparatively smaller, but their dimensions felt within Starmach's (1983) limits for the species.

Xavier (1994) referred this species as P. agilis var. agilis to the plankton of the Ninféias reservoir in the São Paulo Botanical Garden and of some unnamed ponds in the São Paulo Zoological Park, both localities within 
the city of São Paulo; and Menezes (1994) to the plankton and sediments, always among other Euglenophytes, in the state of Rio de Janeiro. Present specimens were always planktonic.

Cryptoglena skujae occurred during the spring, summer and fall, and always in low numbers (two or three specimens per preparation).
Monomorphina nordstedtii (Lemmermann) Popova, Flora Plant. Cryptog. URSS. 3(1):37, pl. 7, fig. 5-6. 1966. Figures 6-7

Cell pyriform, ca. $37.9 \times 21.3 \mu \mathrm{m}, \mathrm{R} \mathrm{l} / \mathrm{b}=$ ca. 1.8 . Geographical distribution: Asia, Europe, North America and South America (as Phacus nordstedtii).

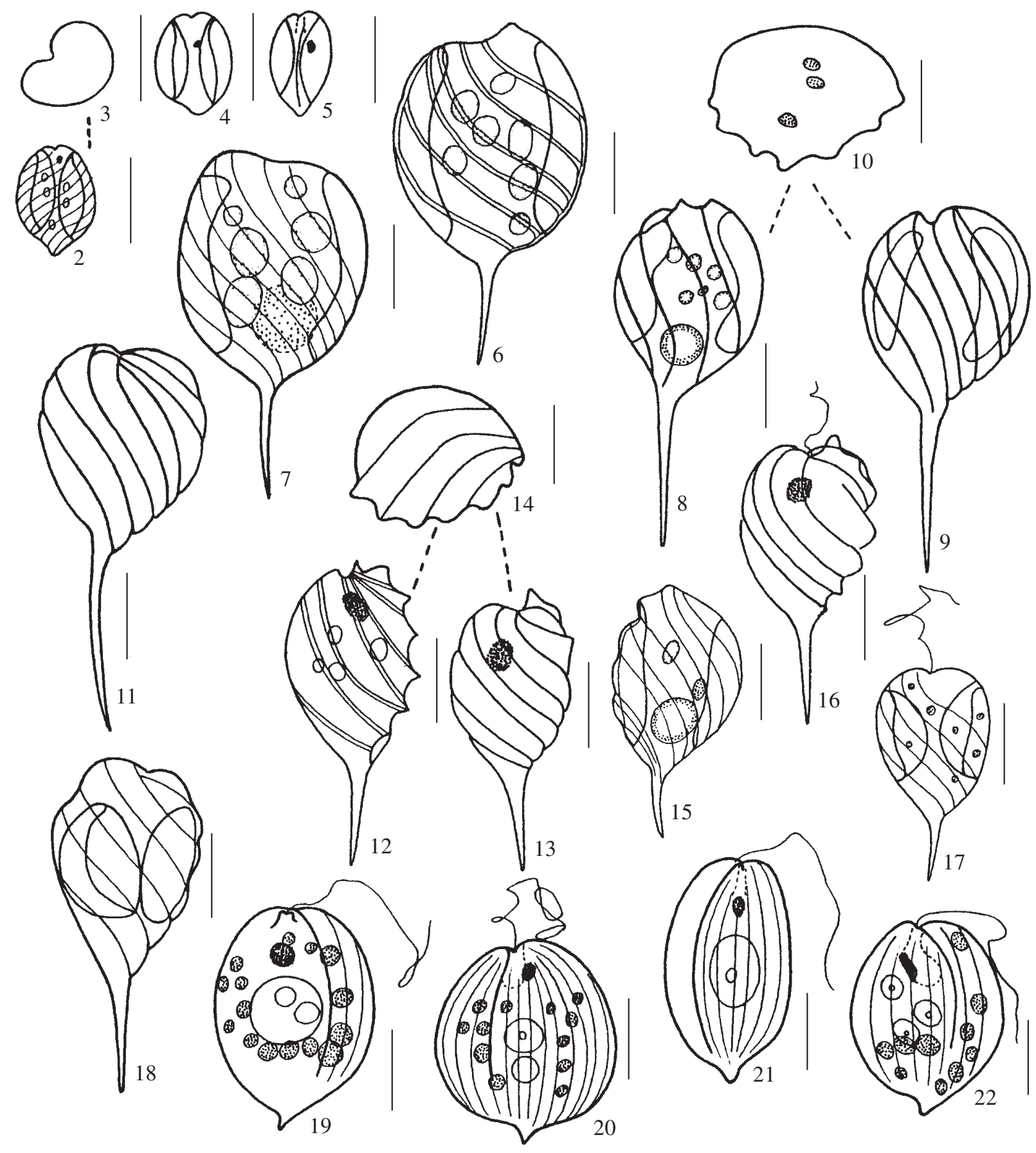

Figures 2-22. 2-5. Cryptoglena skujae. 6-7. Monomorphina nordstedtii. 8-18. Monomorphina pyrum var. pyrum. 11. Detail of striae. 10, 14. Optical transverse section. 19-22. Phacus acuminatus var. acuminatus. 21 . Lateral view. (bar = $10 \mu \mathrm{m})$. 
Specimens examined: HAS26699.

Comments: Monomorphina nordstedtii differs from all other species in the genus in its relatively wider cells, i.e. their unique somewhat rounded outline is never seen in other species of the section.

Representative specimens of Monomorphina nordstedtii were extremely rare, occurring in just one sample unit during the whole study period during the fall.

Monomorphina pyrum (Ehrenberg) Mereschkowsky emend. Kosmala \& Zakryś, J. Phycol. 43:177, 179, fig. 1-11, 13-15, 17. 2007.

Figures 8-18

Cell pear-shaped, $25-46 \times 11.6-16.7 \mu \mathrm{m}, \mathrm{R} 1 / \mathrm{b}=2-2.5$. Geographical distribution: cosmopolitan.

Specimens examined: HAS26680, HAS26684, HAS26685, HAS26691, HAS26692, HAS26695, HAS26696, HAS26699, HAS26702, HAS26703, HAS26709, HAS26710, HAS26713, HAS26732, HAS26733, HAS26735, HAS26736, HAS26745 and HAS26785.

Comments: Kosmala et al. (2007b) revised systematically and phylogenetically the genus Monomorphina on the basis of morphological and molecular data (SSU rDNA), showing that their representative specimens have a single parietal chloroplast and the oldest ones plastids either disintegrated or perforated, giving the specimens under the light microscope the false impression of having several chloroplasts. Kosmala et al. (2007b) emended Monomorphina original description and designated $M$. pyrum its type species. Same authors also considered several taxa of Pochmann's (1942) section Pleurapsis synonymous with $M$. pyrum, thus broadening the species metric limits to 25-46 $\mu \mathrm{m}$ long and 9-19 $\mu \mathrm{m}$ broad.

Monomorphina pyrum was previously collected in Brazil in the States of Amazonas, Goiás, Rio Grande do Sul, Rio de Janeiro and the Federal District, and identified as Phacus pyrum.

Presence of M. pyrum was documented during the fall, winter and summer.

Phacus acuminatus Stokes var. acuminatus, Amer. Monthly Microscop. J. 6:183. 1985.

Figures 19-22

Cell oval, 25.9-27.2 $\times 18.5-20.8 \mu \mathrm{m}, \mathrm{R} 1 / \mathrm{b}=1.2-1.5$. Geographical distribution: cosmopolitan.

Specimens examined: HAS26684, HAS26685, HAS26691, HAS26692, HAS26699, HAS26709, HAS26710 and HAS26797.
Comments: in spite of the fact that cell breadth measurements of presently examined specimens are very close to the minimum limits established for var. acuminatus, its overall morphology fully agreed with that of the species' type variety in Pochmann (1942), Huber-Pestalozzi (1955), Németh (1980) and Tell \& Conforti (1986), who referred to the following cell dimensions: $25-30 \times 18-27 \mu \mathrm{m}$.

Specimens were collected only during the summer and fall, and always in low numbers (two or three per preparation).

Phacus acuminatus Stokes var. variabilis (Lemmermann) Pochmann, Arch. Protistenk. 95(2):143, fig. 32g-h. 1942. Figures 23-24

Cell broadly elliptic to ovate, ca. $25.9 \times 18.5 \mu \mathrm{m}$, $\mathrm{R} 1 / \mathrm{b}=\mathrm{ca} .1 .4$. The variety differs from the typical of the species in having a comparatively less sharply pointed caudus, which is positioned more or less displaced from the cell longitudinal median axis.

Geographical distribution: Europe and South America.

Specimens examined: HAS26699, HAS26702, HAS26703, HAS26709 and HAS26710.

Comments: representative individuals of $P$. acuminatus are morphologically similar to those of $P$. minutus (Playfair) Pochmann and P. circulatus Pochmann, the metrical limits proposed for the three species being $25-30 \times 18-27 \mu \mathrm{m}, 20-28 \times 11-22 \mu \mathrm{m}$ and $28 \times 21 \mu \mathrm{m}$, respectively. However, $P$. acuminatus differs from the two preceding species in having more conspicuous dorsiventrally compressed cells. One accessory characteristic for identification of $P$. acuminatus is the very typical kind of cell movement, which takes place by a constant alternate turning of about $45^{\circ}$ to the right and to the left.

Phacus pseudocarinatus Weik and P. acuminatus var. variabilis specimens were identified from the same sample unit. They can be mistaken one from another because of their ovate cells, relatively smaller cell dimensions, and paramylum granules of two different kinds. However, the most prominent, distinctive characteristics between these two taxa are the bilaterally asymmetrical cells of $P$. pseudocarinatus and its transverse optical section. Up to now, var. variabilis was documented only from the Federal District and for the state of Rio Grande do Sul.

Specimens were only gathered during the summer and fall, and always in low numbers (two or three per preparation). 
Phacus contortus Bourrelly in Bourrelly \& Manguin, Algues d'eau douce Guadalupe. 177, pl. 22, fig. 271-277. 1952.

Figures 25-30

Cell asymmetrical, ovate, twisted, divided in 2 unequal portions, one of them posteriorly expanded, wing-like, oblique, margins differently thickened, 41.6$46.6 \times 33-34.2 \mu \mathrm{m}, \mathrm{R} 1 / \mathrm{b}=1.2-1.3$.
Geographical distribution: cosmopolitan.

Specimens examined: HAS26684, HAS26685, HAS26691, HAS26692, HAS26702, HAS26703 and HAS26741.

Comments: the type-variety of the species is defined by having strongly twisted cells, with two furrows (sulcus) that divide the cell in two unequal portions, and the cuneate transverse optical section of cell, which is 2-sulcate with rounded angles.
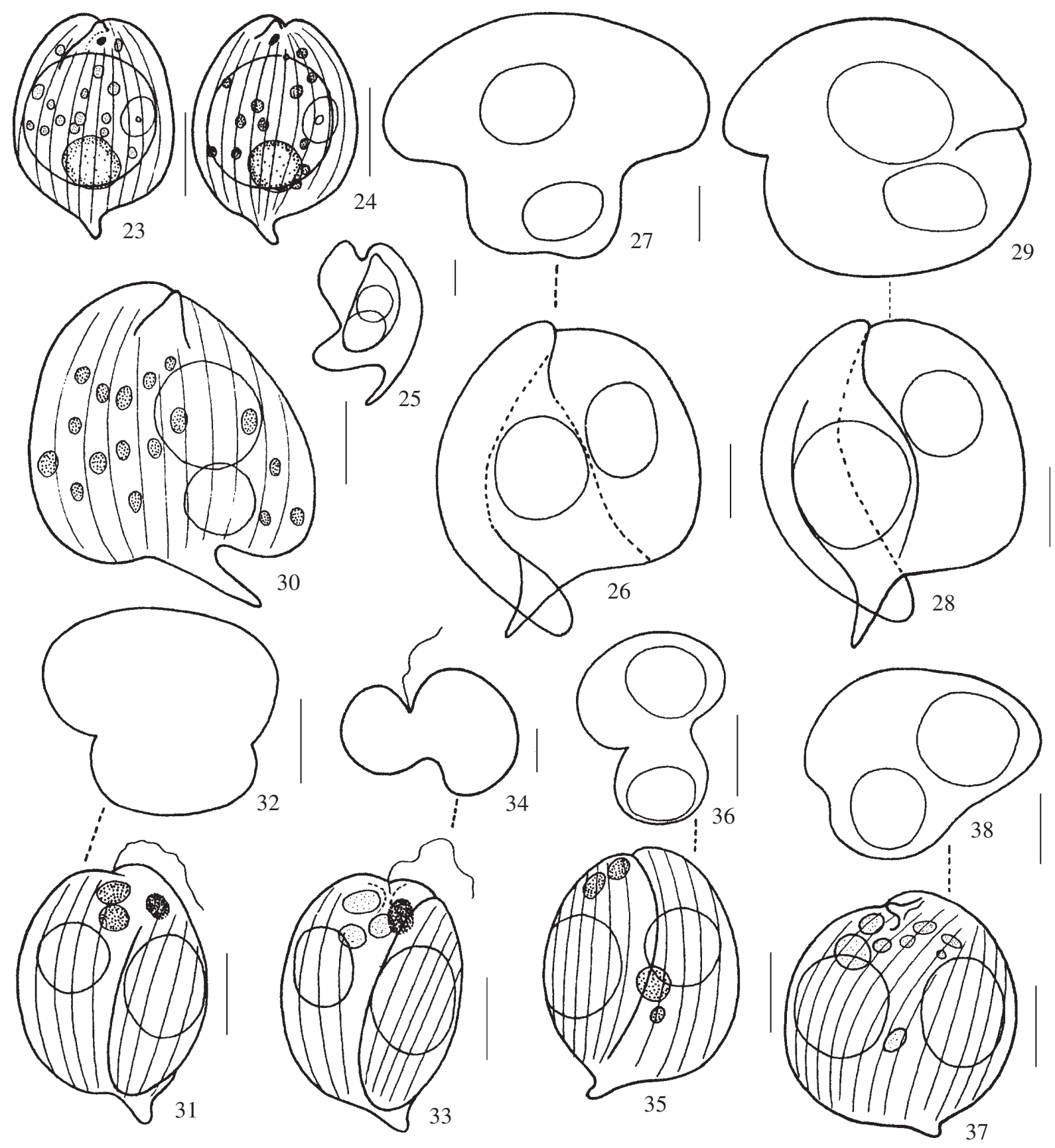

Figures 23-38. 23-24. P. acuminatus var. variabilis. 25-30. P. contortus var. contortus. 27-29. Optical transverse section. 31-38. P. curvicauda. 32, 34-36, 38. Optical transverse section. $(\mathrm{bar}=10 \mu \mathrm{m})$. 
Bourrelly \& Manguin (1952) classified $P$. contortus var. contortus in the species group that includes $P$. anomalus Fritsch \& Rich and P. curvicauda, both presenting a very conspicuous cell torsion. Weik (1967) differed $P$. contortus var. contortus from the two above mentioned species by having greater cell dimensions and the cell divided into two very conspicuous unequal portions.

There are several documents of the occurrence of $P$. contortus in Brazil. Both measurements and cell length:cell breadth ratio of present specimens are within the variation range of the Brazilian material: $30-48 \times$ 18.5-36 $\mu \mathrm{m}$.

Alves-da-Silva \& Torres (1994) observed individuals of this species living in waters with $\mathrm{pH}$ varying between 6.3 and 10.3 , i.e. from acidic to alkaline, and water temperature between 12 and $32^{\circ} \mathrm{C}$. Present observations confirm those of Tell \& Conforti (1986) that $P$. contortus has a very broad geographical distribution, from tropical to temperate.

Phacus contortus var. contortus was collected at all four climatic seasons.

Phacus curvicauda Swirenko, Arch. Hydrobiol. Planktonk. 10:333, pl. 2, fig, 13-16. 1915.

Figures 31-38

Cell symmetrical or asymmetrical, ovate, twisted, margins even or unevenly thickened, usually ventrally projected into a wing-like, oblique expansion, 30.5-34.2 $\times 21.3-24.9 \mu \mathrm{m}, \mathrm{R} \mathrm{l} / \mathrm{b}=1.2-1.4$.

Geographical distribution: cosmopolitan.

Specimens examined: HAS26680, HAS26684, HAS26685, HAS26691, HAS26692, HAS26699, HAS26702, HAS26703, HAS26709, HAS26710, HAS26713, HAS26714, HAS26716, HAS26720, HAS26732, HAS26735, HAS26745 and HAS26773.

Comments: according to Pochmann (1942), $P$. curvicauda is a well characteristic species despite of presenting a wide range of variation in cell dimensions and paramylum granules shape and dimensions, which includes many intermediate forms. Such a heterogeneity was already mentioned by Cardoso (1982), Menezes (1986, 1991, 1994), Menezes et al. (1995) and Xavier (1989, 1994).

Phacus curvicauda morphologically closely resembles $P$. anomalus, the difference between them lying in the transverse optical section that is cuneate with rounded angles in $P$. anomalus and sigmoid or dumb-bell-shaped in P. curvicauda. Degree of cell twisting and cell sulcus also helps in the distinction of these two species.
Observation of populations containing specimens with different margin thicknesses and a wide, continuous variation spectrum of cell shape due to the presence of paramylum granules led us to accept Menezes (1994) proposition of considering $P$. curvicauda Swirenko and $P$. anomalus Fritsch \& Rich heterotypical (taxonomic) synonyms.

Pochmann (1942) mentioned that $P$. curvicauda is common in still waters, Cardoso (1982), Cecy (1990) and Alves-da-Silva \& Torres (1994) adding that the species is frequently found in polluted waters rich in organic matter.

Individual specimens of $P$. curvicauda were collected all year round.

Phacus hamatus Pochmann, Arch. Protistenk. 95(2):182, fig. 86a-f. 1942.

Figures 39-43

Cell ovate, $43.5-45.3 \times 28.6-29.6 \mu \mathrm{m}, \mathrm{R} 1 / \mathrm{b}=1.5-1.6$.

Geographical distribution: cosmopolitan.

Specimens examined: HAS26699, HAS26702, HAS26703, HAS26735, HAS26736 and HAS26745.

Comments: two morphological features that help very much the identification of $P$. hamatus are the cupshaped transverse optical section of the cell and the much more curved, hook-like caudus in the cell lateral view.

There are several documents of the occurrence of $P$. hamatus in Brazil. Specimens presently identified coincided with the morphological description and metrical limits of P. hamatus in Pochmann (1942: 38$55 \times 25-35 \mu \mathrm{m})$.

Presence of $P$. hamatus in the contention basin $\mathrm{n} .7$ was detected during the fall and winter.

Phacus longicauda (Ehrenberg) Dujardin var. longicauda, Hist. nat. Zoophytes. 337, pl. 5, fig. 6. 1841.

Figure 44

Cell obvate, 101-122 × 37-44.6 $\mu \mathrm{m}, \mathrm{R} 1 / \mathrm{b}=2.5-2.7$. Geographical distribution: cosmopolitan.

Specimens examined: HAS26680, HAS26684, HAS26685, HAS26691, HAS26692, HAS26699, HAS26702, HAS26703, HAS26709, HAS26710, HAS26713, HAS26714, HAS26716, HAS26720, HAS26732, HAS26733, HAS26735, HAS26736, HAS26741, HAS26742, HAS26745, HAS26751, HAS26755, HAS26761, HAS26765, HAS26773, HAS26776, HAS26781, HAS26785, HAS26788, HAS26797, HAS26800 and HAS26804.

Comments: separation of the taxonomical varieties of $P$. longicauda is not an easy task. We presently consider 
that the morphological and metric circumscriptions of $P$. longicauda var. longicauda include those of var. insecta (Koczwara) Skvortzov, var. cordata (Pochmann) Huber-Pestalozzi, var. attenuata Pochmann and var. rotunda Pochmann. Variety insecta was included because some specimens presently studied showed cell marginal incisions after fixation with formalin and/or lugol solution, despite of the fact that such characteristics were never observed in living material.

Phacus longicauda has been widely collected in Brazil. Presence of $P$. longicauda was documented during the four climatic seasons of the year and in about $77 \%$

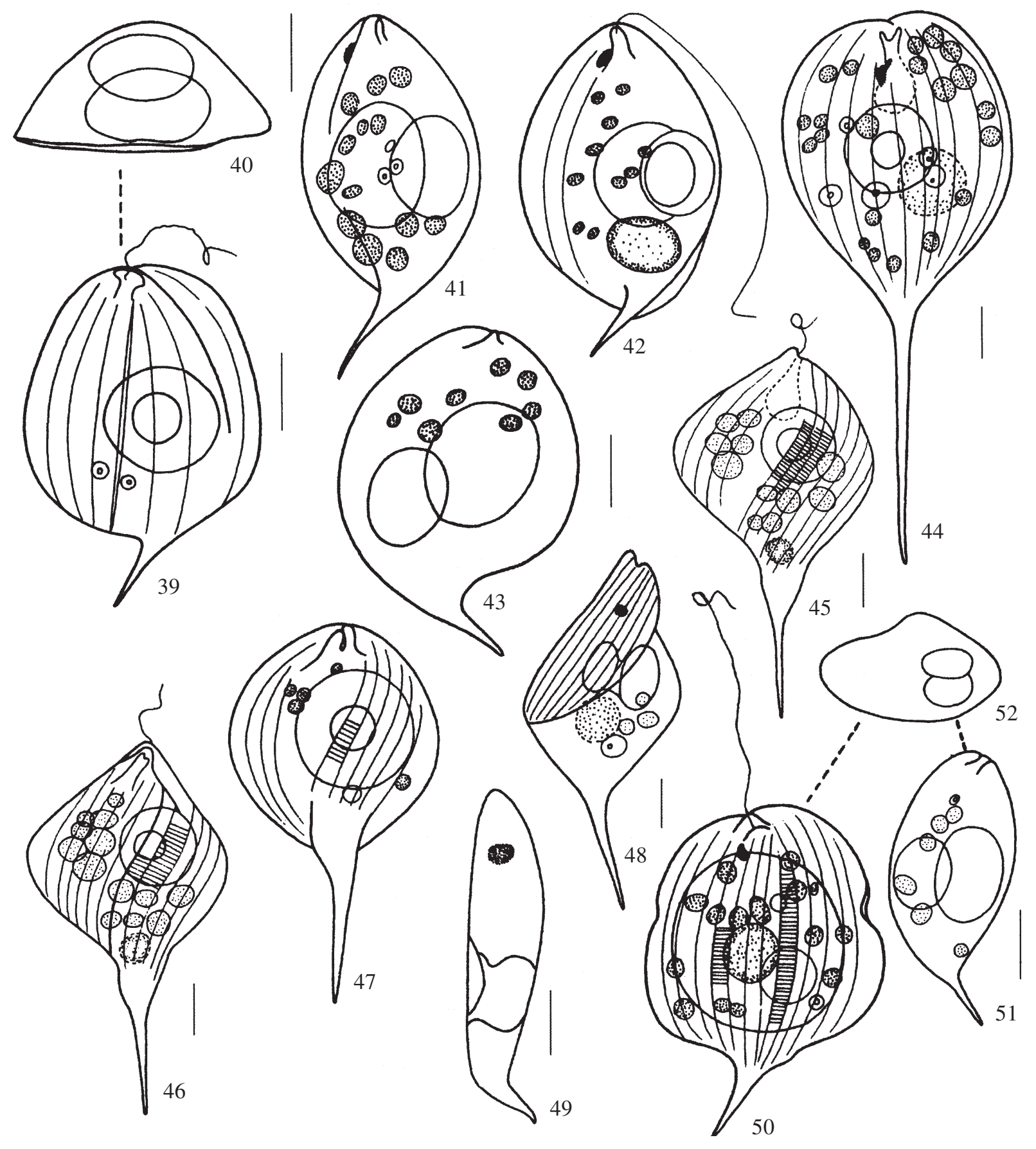

Figures 39-52. 39-43. Phacus hamatus. 40. Optical transverse section. 41, 42. Lateral view. 44. P. longicauda var. longicauda. 45-48. P. longicauda var. tortus. 45, 46. Detail of transverse striae. 49-52. Phacus orbicularis. 52. Optical transverse section. 49, 51. Lateral view. (Scale bar $=10 \mu \mathrm{m})$. 
of total sampling units examined. Taking into consideration the relative density, $P$. longicauda was among the best represented taxa during the study period. Also, specimens of var. longicauda and var. tortus were always collected together, i.e. they were always present at the same time in more than $66 \%$ of total samples studied.

Phacus longicauda (Ehrenberg) Dujardin var. tortus Lemmermann, Kryptogamenfl. Mark Brandenburg 3:511. 1910.

Figures 45-48

Cell ovate to broadly elliptic, broadest at the anterior portion, $64.7-80.9 \times 33.3-41.6 \mu \mathrm{m}, \mathrm{R} \mathrm{l} / \mathrm{b}=1.9-2.5$. The variety differs from the typical in the cell torsion at its mid region, which completes a full turn, and in the presence of transverse striae in between the longitudinal ones.

Geographical distribution: cosmopolitan.

Specimens examined: HAS26680, HAS26684, HAS26685, HAS26691, HAS26692, HAS26699, HAS26702, HAS26703, HAS26713, HAS26714, HAS26716, HAS26732, HAS26733, HAS26741, HAS26742, HAS26745, HAS26751, HAS26773, HAS26781, HAS26785, HAS26792, HAS6797, HAS26800, HAS26804 and HAS26809.

Comments: populations of $P$. longicauda (Ehrenberg) Dujardin var. longicauda and $P$. longicauda var. tortus Lemmermann [ $=$ P. tortus (Lemmermann) Skvortzov] were observed in the very same sampling unit displaying half a cell torsion at the base of the caudus in P. longicauda var. longicauda and a complete torsion at the cell mid region in P. longicauda var. tortus. Overlapping of cell measurements between the two above populations was never detected. Absence of transverse striae in between the longitudinal ones in var. longicauda and their presence in var. tortus is another good feature to distinguish the two varieties (figures 45-47).

Specimens in the present study were identified with P. longicauda var. tortus based on Németh (1980) that considered $P$. tortus (Lemmermann) Skvortzov a synonym of $P$. longicauda var. tortus. According to the literature (Németh 1980, Starmach 1983, Pochmann 1942, Skvortzov 1928, among others), metrical limits of var. tortus are 80-112 $\times 38-52 \mu \mathrm{m}$. Some individual specimens, however, presented somewhat smaller dimensions for the cell length than it was mentioned in the literature, but that agreed with those for Brazilian material in Jati \& Train (1994:60.8-85 $\mu \mathrm{m})$, Franceschini (1992:62.5-118 $\mu \mathrm{m})$ and Alves-da-Silva \& Torres (1994:64.7-115.5 $\mu \mathrm{m}$ ).

Phacus longicauda var. tortus was mentioned several times for Brazil as P.tortus. The species was presently collected during all four climatic seasons. It was very well represented during almost the entire year, being identified from nearly $65 \%$ of total samples collected.

Phacus orbicularis Hübner emend. Zakryś \& Kosmala, J. Phycol. 43:1077, fig. 1f-j, m-n, p, r-s, u. 2007.

Figures 49-54

Cell broadly ovate to globose, $46.2-92.5 \times 28.7-$ $64.7 \mu \mathrm{m}, \mathrm{R} \mathrm{l} / \mathrm{b}=1.3-1.6$.

Geographical distribution: cosmopolitan.

Specimens examined: HAS26691, HAS26692, HAS26699, HAS26702, HAS26703, HAS26713, HAS26714, HAS26716, HAS26735, HAS26736, HAS26741, HAS26742, HAS26745, HAS26751, HAS26755, HAS26761, HAS26765, HAS26773, HAS26781, HAS26788, HAS26800 and HAS26804.

Comments: three distinct populations of $P$. orbicularis were presently considered, which could be identified as follows: the first one included the specimens with the smallest cell dimensions $(46.2-53.6 \times 28.7-37 \mu \mathrm{m}, \mathrm{R} 1 / \mathrm{b}$ =1.4-1.6); the second one the specimens with intermediate cell dimensions $(71.2-74 \times 49 \mu \mathrm{m}, \mathrm{R} \mathrm{1} / \mathrm{b}=1.4-1.5)$; and the third one the specimens with the greatest cell dimensions (75.8-92.5 $\times 54.7-64.7 \mu \mathrm{m}, \mathrm{R} 1 / \mathrm{b}=1.3-1.4)$. According to Pochmann (1942), measurements vary considerably in this species as well as the cell morphology. The latter author referred to the following cell dimensions for $P$. orbicularis: $50-100 \times 30-60 \mu \mathrm{m}$ and Tell \& Conforti (1986) broadened such limits to $32-100 \times 22-60 \mu \mathrm{m}$.

All three populations presently studied showed 3-angular cell transverse optical section, with rounded angles, and fine numerous struts perpendicular to the longitudinal axis located between pellicle strips. Some individuals, however, showed marginal notches immediately after fixation with $4 \%$ formaldehyde solution (figure 50).

Kosmala et al. (2007a) taxonomically revised the genus Phacus based on its morphological and molecular data and, consequently, emended de original description of $P$. orbicularis providing the species a broader dimension spectrum: $29-75 \times 22-49 \mu \mathrm{m}$, and considering the presence of longitudinal and transverse striae an important feature for the species identification.

Morphological and metrical circumscriptions of all three populations studied agree with the original description for the species in Pochmann (1942) and Kosmala et al. (2007a), except for the cell dimension of the specimens of the third population.

Populations examined were collected during all four climatic seasons of the year. 


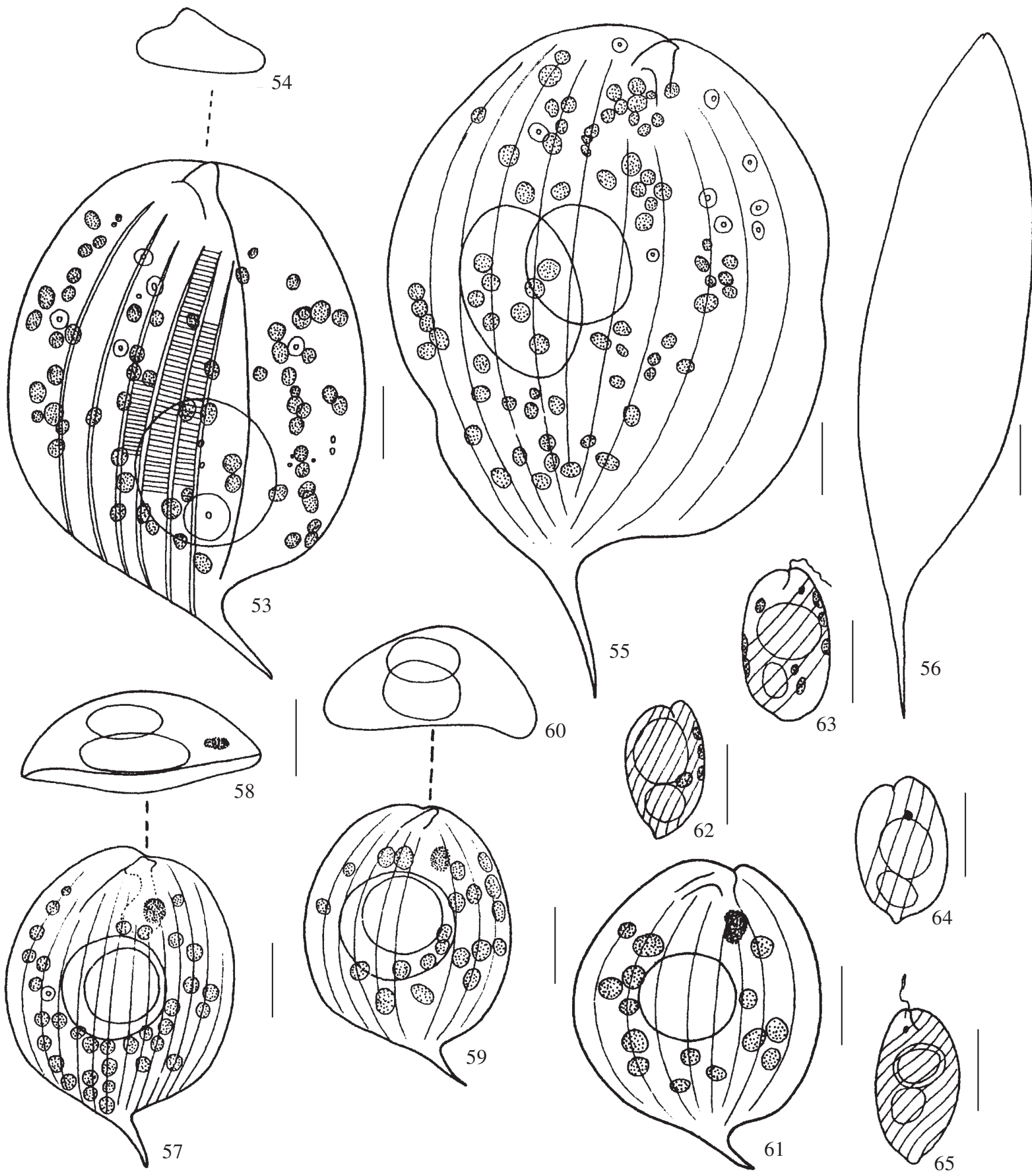

Figures 53-65. 53-54. Phacus orbicularis. 54. Optical transverse section. 55-56. P. platalea. var. major. 56. Lateral view. 57-61. P. pleuronectes. 58, 60. Optical transverse section. 62-65. P. polytrophos. 64. Detail of striae. 62-65. Detail of the ring-shaped paramylum $(\mathrm{bar}=10 \mu \mathrm{m})$. 
Phacus platalea Drezepolski var. major De-Pouques in Huber-Pestalozzi, Phytoplankt. Susswässers 16(4):551, fig. 1121. 1955.

Figures 55-56

Cells broadly ovoid to nearly spherical, 115.4-125 $\times 78-92.5 \mu \mathrm{m}, \mathrm{R} 1 / \mathrm{b}=1.4-1.6$. This variety differs from the typical in having greater cell dimensions and a comparatively longer caudus, 16-24 $\mu \mathrm{m}$ long.

Geographical distribution: Europe, North America and South America.

Specimens examined: HAS26680, HAS26735, HAS26736 and HAS26761.

Comments: Zakryś and Kosmala in Kosmala et al. (2007a) considered $P$. platalea a synonym of $P$. orbicularis based on molecular data, but, the present var. major was not studied. Present identification with $P$. platalea var. major is conditional, until this taxonomical variety will be better studied.

The species was formerly found only in the states of Amazonas and Rio Grande do Sul. It always occurs in low numbers, in the midst of organic matter originated from decomposition.

Phacus platalea var. major was collected during the summer, winter and spring.

Phacus pleuronectes (O.F. Müller) Dujardin emend. Zakryś \& Kosmala, J. Phycol. 43:1077, fig. 1c-e. 2007. Figures 57-61

Cell ovate to globose, $38.1-47.2 \times 26.8-30.5 \mu \mathrm{m}$. $\mathrm{R} 1 / \mathrm{b}=1.4-1.5$.

Geographical distribution: cosmopolitan.

Specimens examined: HAS26680, HAS26691, HAS26692, HAS26699, HAS26702, HAS26703, HAS26709, HAS26710, HAS26713, HAS26714, HAS26716, HAS26720, HAS26732, HAS26733, HAS26735, HAS26736, HAS26741, HAS26742, HAS26745, HAS26755, HAS26761, HAS26765, HAS26773, HAS26785 and HAS26792.

Comments: there are several records of the occurrence of $P$. pleuronectes in Brazil, as well as in many countries throughout the world, making it one of the most cosmopolitan species of the genus. Metrical variation range of $P$. pleuronectes specimens gathered in the Brazilian territory is $35-76 \times 23-42 \mu \mathrm{m}$ which, consequently, falls within the circumscription usually referred in literature.

The species is well represented in the contention basin $n .7$ occurring in about $67 \%$ of all sampling units studied and always in considerably high numbers.

Phacus pleuronectes was collected at all climatic seasons of the year.
Phacus polytrophos Pochmann, Arch. Protistenk. 95(2): 128, fig. 15a-d. 1942.

Figures 62-65

Cell elliptical, $15.7-18.5 \times 7.4-10.2 \mu \mathrm{m}, \mathrm{R} 1 / \mathrm{b}=$ 1.7-2.2.

Geographical distribution: Asia, Europe, North America and South America.

Specimens examined: HAS26691, HAS26692, HAS26695, HAS26696, HAS26699, HAS26702 and HAS26703.

Comments: according to Pochmann (1942), the somewhat oblique position of the paramylum granules in the cell is characteristic for the present species. Yet for the same author, the apical sulcus is short and the striae twisted to the right whereas for Tell \& Conforti (1986) striae are twisted to the left.

Phacus polytrophos morphologically resembles $P$. granum Drezepolski from which differs in the striae that are longitudinal in the latter, and in the presence of two or more rod-shaped paramylum granules whose angles are approximately rectangular, whereas in $P$. polytrophos striae are twisted to the right and the two paramylum granules are disc or rod-shaped with rounded angles and are placed at a somewhat oblique position in the cell.

Present is the fourth register of the occurrence of the species in Brazil. First one was for Castanho Lake, in the state of Amazonas by Uherkovich \& Schmidt (1974), and the second and third ones were for the states of Goiás and Tocantins by Menezes et al. (1995). Specimens presently examined were slightly smaller as well as the cell length:cell breadth ratio when compared to Uherkovich \& Schmidt's (1974). However, both limits were very close to the minimum for the cell size and the length:breadth ratio in Menezes et al. (1995).

Phacus polytrophos was collected only during the summer and fall in the system studied.

Phacus pseudobicarinatus Alves-da-Silva \& C. Bicudo, sp. nov.

Typus: Brazil, Provincia Rio Grande do Sul, Municipium Triunfo, lacus artificialis no 7, II-1995, S.M. Alves da Silva, s.n. (HAS26680) (Holotypus HAS) Figures 66-76

Cellula fortiter asymmetrica, ovata, 29,6-30,5 × 22,7-24,9 $\mu \mathrm{m}, R \mathrm{c} / \mathrm{l}=1,1-1,2$; sulcus verticis fere quam cellula longior, margo dextra fortiter convexa, sectio optica transversalis leviter triangularis, anguli rotundati; polus posterior abrupte attenuatus processo caudali hyalino, conico, curvato, 2-3 $\mu$ m longo, pelicula hyalina, 


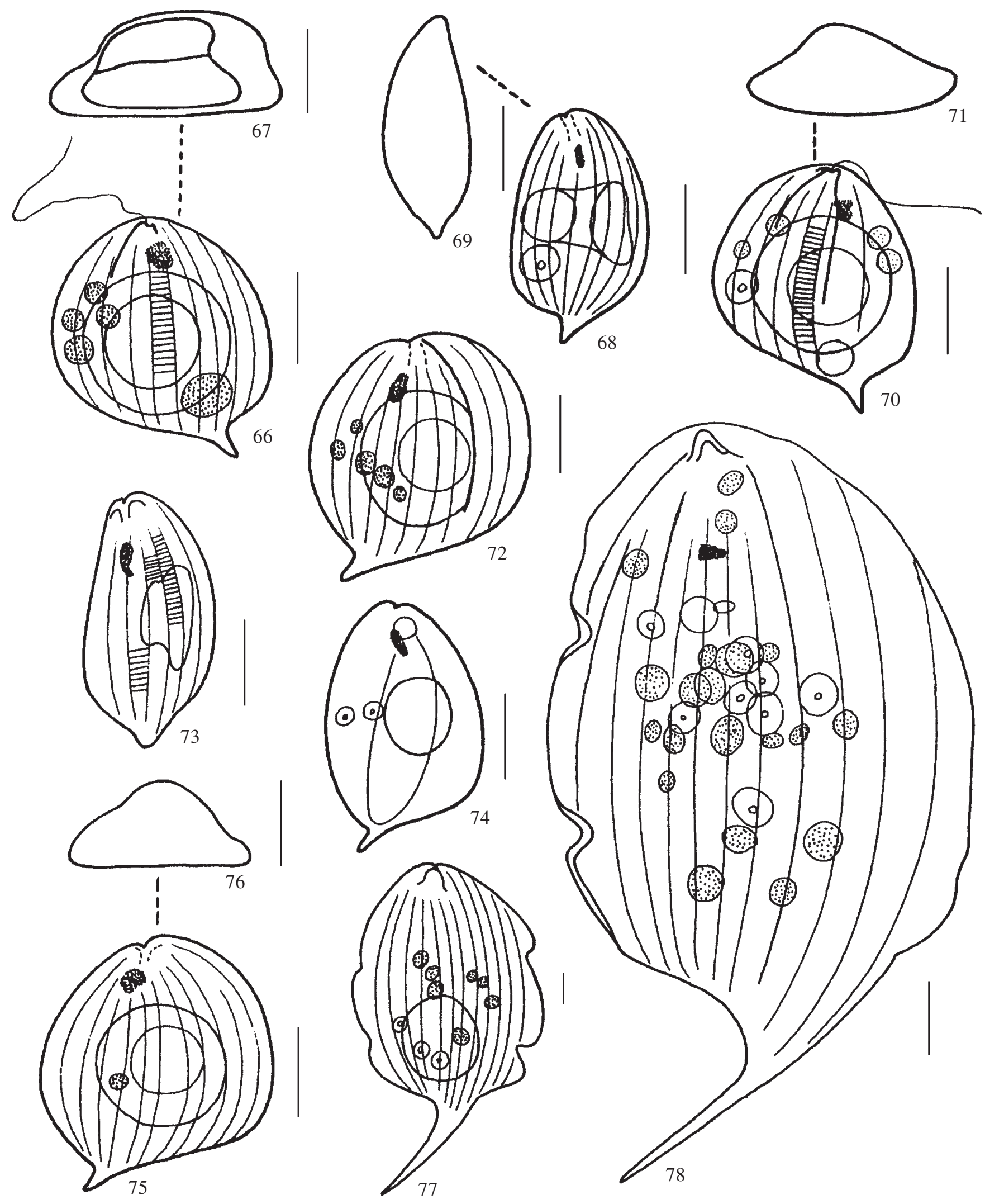

Figures 66-78. 66-76. Phacus pseudobicarinatus sp. nov. 67, 71, 76. Optical transverse sections. 69, 73, 74. Lateral view. 77-78. P. undulatus f. major. $(\mathrm{bar}=10 \mu \mathrm{m})$. 
striae longitudinales et transversales; chloroplasti parietales, numerosi, discoidei, ca. 2,8 $\mu$ m diam.; granula paramylacea 2, concentrica, frequenter centralia, minora ca. 6,5 4 m diam., maiora ca. 12 um diam., alia minora, sphaerica, dispesa; aspectu laterali granula paramylacea penioniformia; nucleus posterior, 4,4-5,6 нm diam.; flagellum 0,5-1-plo cellulae longitudo.

Cell strongly asymmetrical, ovate, $29.6-30.5 \times 22.7-$ $24.9 \mu \mathrm{m}, \mathrm{R} 1 / \mathrm{b}=1.1-1.2$; sulcus almost as long as the cell, right margin strongly convex, transverse optical section 3-angular, rounded angles, posterior pole suddenly attenuate into a hyaline, conical, curved towards the cell right margin, 2-3 $\mu \mathrm{m}$ long caudus; pellicle hyaline, striae longitudinal and transversal; chloroplasts parietal, numerous, disc-shaped, ca. 2,8 $\mu \mathrm{m}$ diam.; paramylum granules 2, concentric or not, usually central, small one ca. $6.5 \mu \mathrm{m}$ diam., large one ca. $12 \mu \mathrm{m}$ diam., a few other smaller, spherical, dispersed, diameter not measured; lateral view of paramylum granules bobbin-like; nucleus posterior; stigma elongate to 3-angular; flagellum 0.5-1 times the cell length.

Geographic distribution: Brazil.

Adicional specimens examined: HAS26680, HAS26684, HAS26685, HAS26691, HAS26692, HAS26695, HAS26696, HAS26699, HAS26702, HAS26703, HAS26709, HAS26710, HAS26713, HAS26716, HAS26735, HAS26745, HAS26755, HAS26761, HAS26781, HAS26785 and HAS26792.

Comments: specimens seen showed strong cell asymmetry, striae transversal, transverse optical section slightly triangular with rounded angles and paramylum granules bobbin-shaped in lateral view. Despite of being sometimes superficial, presence of fine transverse striae indicate some similarity with the decoration pattern of the $P$. orbicularis species group.

Phacus pseudobicarinatus specimens morphologically resemble those of $P$. bicarinatus Weik and $P$. denisii Allorge \& Lefevre, from which are different in their strong cell asymmetry due to the strongly convex right margin. Regarding the transverse optical section, $P$. bicarinatus presents two humps and $P$. denisii is triangular, with rounded angles, whereas $P$. pseudobicarinatus has slightly triangular transverse optical section with rounded angles and has transverse striae.

Present species was present in the reservoir during the four seasons of the year.

Phacus undulatus (Skvortzov) Pochmann f. major (Prescott) Huber-Pestalozzi, Phytoplankt. Susswässers 16(4):215, pl. 47, fig. 287B. 1955.

Figures $77-78$
Cell ovoid, 110.2-115 × 61.3-66.9 $\mu \mathrm{m} . \mathrm{R}$ 1/b = 1.61.8. Present variety differs from the typical of the species solely in the greater cell dimensions.

Geographical distribution: Europe and South America.

Specimens examined: HAS26702, HAS26703, HAS26741 and HAS26742.

Comments: specimens studied were morphologically similar to those of $P$. platalea var. major due to the following: 1) comparatively great cell dimensions; 2) cell ovoid; and 3) marginal notches present. They differ, however, in the caudus and in the cell shape. Thus, in $P$. undulatus f. major caudus is much more curved, cell is much more elongate and apical sulcus extends almost to the cell posterior portion, whereas in $P$. platalea var. major caudus is not so curved, cell is much broader and the specimens have their overall morphology, as well as its length measurements are very similar to that in HuberPestalozzi (1955) and Starmach (1983), except for the cell breadth that was slightly greater.

Zakryś and Kosmala in Kosmala et al. (2007a) considered $P$. orbicularis a synonym of $P$. undulatus on the basis of molecular biology information. We do not agree, however, with their position, because the main diagnostic feature considered by them to identify $P$. orbicularis is the presence of transverse striae in between the longitudinal ones, which are never observed in $P$. undulatus was not challenged. Also, $P$. undulatus var. major was not studied by Kosmala et al. (2007a). Until more studies are carried out, present specimens will remain identified with $P$. undulatus var. major.

This variety was considered rare in the system studied, since it occurred in just two of the 14 sampling months. It was also rare due to the fact that it occurred just sporadically in the sample it was detected.

Phacus undulatus f. major was collected only during the fall and winter.

Final remarks - Distinction between $P$. anomalus and $P$. curvicauda lies in the size of the paramylum granule, which is comparatively greater in the first one. Conrad (1943) just mentioned and Kosmala et al. (2007a) proved that the excessive development of paramylum granules, mainly in the foliose cells, as is the case of the genus Phacus, may cause pellicle distention and consequent modification of the cell shape, a fact that may lead to problems during the proper taxonomic identification of such organisms.

We believe that $P$. anomalus is nothing but a morphological expression of $P$. curvicauda and if this is 
true, the former must be considered a heterotypical (taxonomical) synonym of the latter. However, confirmation of such a synonymy demands the study of both species in culture and knowledge of their molecular sequences.

Huber-Pestalozzi (1955) considered P. helicoides Pochmann and $P$. sesquitortus Pochmann taxonomic varieties of $P$. tortus, since environmental factors such as temperature, light and $\mathrm{pH}$ may affect the degree of cell twisting. Pringsheim (1948) stated that cell torsion in Euglena species is not a constant feature, since it could be affected by the cell metabolism itself. Starmach (1983) considered $P$. tortus a variety of $P$. longicauda and included all other species with twisted cell ( $P$. morii Skvortzov, P. multiannulatus Pochmann, P. circumflexus Pochmann, P. ephippion Pochmann, P. sesquitortus Pochmann, P. helicoides Pochmann, P. tortus (Lemmermann) Skvortzov var. roeckli Pochmann and $P$. similis Christiansen) in the synonymy of $P$. longicauda var. torta. Németh (1980) also considered $P$. tortus a variety of $P$. longicauda. During the present study, specimens of $P$. longicauda var. longicauda and $P$. longicauda var. tortus were observed associated in the same sample and morphologically well separated from each other.

The best represented taxa during the study period because were collected all year round and occurred in a great number of sampling units or presented high relative densities were: P. longicauda, P. longicauda var. tortus, $P$. orbicularis, $P$. pleuronectes and $P$. pseudobicarinatus.

Cryptoglena skujae, Monomorphina pyrum, Phacus acuminatus, $P$. contortus var. contortus, $P$. hamatus, $P$. longicauda, $P$. longicauda var. tortus, $P$. orbicularis and $P$. pleuronectes are cosmopolitan. All other species occurred in just two or three localities.

Monomorphina nordstedtii and P. undulatus $\mathrm{f}$. major were considered rare because they occurred in at most two of the 14 sampling months.

Phacus pseudobicarinatus, $P$. contortus, $P$. curvicauda, $P$. longicauda, $P$. longicauda var. tortus, $P$. orbicularis and $P$. pleuronectes occurred in all climatic seasons of the year. All other ones were present in one, two or three seasons.

Phacus undulatus f. major is presently cited for the first time for the Brazilian territory.

Sampling station 1 was characteristic for always being shallower than station $2(<1 \mathrm{~m}$ deep) and having in the nearby several bird nests, which may have contributed to its greater species richness since the greatest numbers of Phacus species occurred in this station during eight out of the 14 months studied. Regarding species richness, March/1995 (summer) and April/1995 (fall) should be mentioned due to the presence of 11 taxa at station 1 and 12 at station 2 (table 2).

Despite the fact that February and March (summer/ 1996) have displayed all the conditions to support a high species richness, a decrease in the number of taxa was registered possibly due to the high precipitation registered towards the end of January, and the presence of polyethilene residues in the form of ashes reaching the contention basin in March with reflexes on the presence of only one Phacus species at station 2 in March/1996 (table 2).

Phacus longicauda var. longicauda and $P$. longicauda var. tortus were characteristic by their wide tolerance to the following environmental variables: $\mathrm{pH}$, water temperature, organic matter concentration, total phosphorus and the nitrogen series (nitrite, nitrate, ammonium and total nitrogen) (table 1).

Monomorphina nordstedtii and Phacus polytrophos occurred in $\mathrm{pH}$ acid, while the other species, varieties and taxonomic forma were not selective to $\mathrm{pH}$, being collected in environments that varied from acid to alkaline. Phacus acuminatus var. acuminatus, $P$. platalea var. major, $P$. polytrophos, $P$. undulatus $\mathrm{f}$. major, Cryptoglena skujae, Monomorphina pyrum and $M$. nordstedtii occurred in temperatures ranges below $10{ }^{\circ} \mathrm{C}$; all other species were tolerant to high ranges of temperature (eurithermal).

Alves-da-Silva \& Torres (1994) documented Phacus orbicularis living in shallow lakes with waters with $\mathrm{pH}$ between 5.9 and 10.3 and temperature between $12{ }^{\circ} \mathrm{C}$ and $32{ }^{\circ} \mathrm{C}$. The greatest number of specimens, however, was detected in water with slightly acidic $\mathrm{pH}$ and temperature above $20^{\circ} \mathrm{C}$. Cecy (1990) found this species living in water with $\mathrm{pH}$ between 6.35 and 7.2 and temperature between $20^{\circ} \mathrm{C}$ and $27^{\circ} \mathrm{C}$.

Various authors, Wetzel (1993) among them, mentioned that euglenophytes can be usually collected in deep waters rich in organic matter. Present contention basin is a shallow water body with almost total transparency during the entire study period and organic matter consumption between $0.7 \mathrm{mg} \mathrm{L}^{-1}$ and $6.3 \mathrm{mg} \mathrm{L}^{-1}$.

Acknowledgements - Sandra Maria Alves da Silva acknowledges Capes, Coordenação de Aperfeiçoamento de Pessoal do Ensino Superior, for partial financial support; to Manuel Luís Nunes, for chemical analyses; to George Rodrigues Cunha, for help in the field during the samplings; and to artist Rejane Rosa, for final inking in of the original drawings. Carlos Eduardo de Mattos Bicudo thanks CNPq, Conselho Nacional de Desenvolvimento Científico e Tecnológico for partial financial support (Grant n. 303876/ 2004-2). 


\section{References}

ALVES-DA-SILVA, S.M. \& LAITANO, C.S. 1994. Euglenaceae pigmentadas do Banhado do Jacaré, em um Parque de Proteção Ambiental, Triunfo, Rio Grande do Sul, Brasil. Iheringia, série Botânica 45:89-116.

ALVES-DA-SILVA, S.M. \& TORRES, J.R. 1994. Estudo taxonômico do gênero Phacus Duj. (Euglenaceae) no Parque Zoológico, Sapucaia do Sul e no Jardim Botânico, Porto Alegre, Rio Grande do Sul. Iheringia, série Botânica 44:45-83.

BOURRELLY, P.C. \& MANGUIN, E. 1952. Algues d'eau douce de la Guadaloupe et dépendences recuillies par la mission P. Allorge en 1936. Societé d'Édition Énseignement Superieur, Paris.

BUSSE, I. \& PREISFELD, A. 2002. Phylogenetic position of Rhynchopus sp. and Diplonema ambulator as indicated by analyses of euglenozoan small subunit ribosomal DNA. Gene 284:83-91.

BUSSE, I. \& PREISFELD, A. 2003. Systematic of primary osmotrophic euglenids: a molecular approach to the phylogeny of Distigma and Astasia (Euglenozoa). Journal of Systematics and Evolutionary Microbiology 53:617-624.

CARDOSO, M.B. 1982. Levantamento das Euglenaceae pigmentadas do Distrito Federal, Brasil. Tese de doutorado, Universidade de São Paulo, São Paulo.

CECY, I.T. 1990. A restinga do Pontal do Sul, Município de Paranaguá, PR, 1: levantamento ficológico (Euglenophyta) e físico-químico. Arquivos de Biologia e Tecnologia 33:1-79.

CONRAD, W. 1943. Remarques sur le genre Phacus. Bulletin du Museum Royale de Histoire Naturelle de Belgique 19:1-16.

FRANCESCHINI, I.M. 1992. Algues d'eau douce de Porto Alegre, Brésil (les Diatomophycée excluées). Bibliotheca Phycologica 92:1-81.

GOLTERMAN, H.L., CLYMO, R.S. \& OHNSTAD, M.A.M. 1978. Methods for physical \& chemical analysis of fresh waters. $2^{\text {nd }}$ ed., Blackwell Scientific Publications, Oxford and Edinburg.

HUBER-PESTALOZZI, G. 1955. Euglenaceen. In Das Phytoplankton des Susswässers: Systematik und Biologie (G. Huber-Pestalozzi, ed.). E. Schweizerbart'sche Verlangsbuchhandlug, Stuttgart, v.16, p.1-605.

JATI, S. \& TRAIN, S. 1994. Euglenaceae pigmentadas de ambientes lênticos da ilha Porto Rico, Município de Porto Rico, Paraná, Brasil. Iheringia, serie Botânica, 45:117-142.

KOSMALA, S., BEREZA, M., MILANOWSKI, R., KWIATOWSKI, J. \& ZAKRYŚ, B. 2007a. Morphological and molecular examination of relationships and epitype establishment of Phacus pleuronectes, Phacus orbicularis and Phacus hamelli. Journal of Phycology 43:1071-1082.
KOSMALA, S., MILANOWSKI, R., BRZÓSKA, K., PEKALA, M., KWIATOWSKI, J. \& ZAKRYŚ, B. 2007b. Phylogeny and systematics of the genus Monomorphina (Euglenaceae) based on morphological and molecular data. Journal of Phycology 43:171-185.

LEANDER, B.S., WITEK, R.P. \& FARMER, M.A. 2001. Trends in the evolution of the euglenid pellicle. Evolution 55:2215-2235.

LINTON, E.W., HITTNER, D., LEWANDOWSKI, C., AULD, T. \& TRIEMER, R.E. 1999. A molecular study of euglenoid phylogeny using small subunit rDNA. Journal of Eukariont Microbiology 46:217-223.

LINTON, E.W., NUDELMAN, M.A., CONFORTI, V. \& TRIEMER, R.E. 2000. A molecular analysis of the euglenophytes using SSU rDNA. Journal of Phycology 36:740-746.

MACKERETH, F.J.H., HERON, J. \& TALLING, F.J. 1978. Water analysis: some revised methods for limnologists. Titus Wilson \& Sons Ltd, Kendall.

MARIN, B., PALM, A., KLINGBERG, M. \& MELKONIAN, M. 2003. Phylogeny and taxonomic revision of plastidcontaining Euglenophytes based on SSU rDNA sequence comparisons and synapomorphic signatures in the SSU rDNA secondary structure. Protist 154: 99-145.

MENEZES, M. 1986. Ficoflórula da Chapada dos Guimarães e arredores, Mato Grosso, Brasil: Euglenaceae pigmentadas (Euglenophyceae). Rickia 3:87-95.

MENEZES, M. 1991. O gênero Phacus (Euglenaceae) no Município do Rio de Janeiro e arredores, Brasil. Hoehnea 18:171-189.

MENEZES, M. 1994. Fitoflagelados pigmentados de quatro corpos d'água da região sul do município do Rio de Janeiro, estado de Rio de Janeiro, Brasil. Tese de doutorado, Universidade de São Paulo, São Paulo.

MENEZES, M., NASCIMENTO, E.P. \& FONSECA, C.G. 1995. Criptógamos, Euglenophyceae. In Flora dos Estados de Goiás e Tocantins. (I.F.P. Campos, coord.). Universidade Federal de Goiás, Goiânia. v.4, n.1, p.1-77.

MERESCHKOWSKY, K.S. 1877. Etjudy nad prostejsimi zivotnymi severa Rossii. Trudy Sankt-Peterburgskago Obshchestva Estestvoisptateleǐ 8:1-299.

NÉMETH, J. 1980. Az ostoros Algák (Euglenophyta): Kishatározóija. Vizdock, Budapeste. (série Hidrobiológia 8).

NUDELMAN, M.A., LEONARDI, P.I., CONFORTI, V., FARMER, M.A. \& TRIEMER, R.E. 2006. Fine structure and taxonomy of Monomorphina aenigmatica comb. nov. (Euglenophyta). Journal of Phycology 42:1922002.

POCHMANN, A. 1942. Synopsis der Gattung Phacus. Archiv für Protistenkunde 5:121-252. 
PREISFELD, A., BERGER, S., BUSSE, I., LILLER, S. \& RUPPEL, H.G. 2000. Phylogenetic analyses of various euglenoid taxa (Euglenozoa) based on $18 \mathrm{~S}$ rDNA sequence data. Journal of Phycology 36:220-226.

PREISFELD, A., BUSSE, I., KLINGBERG, M., TALKE, S. \& RUPPEL, H.G. 2001. Phylogenetic position and interrelationships of the osmotrophic euglenoids based on SSU rDNA data, with emphasis on the Rhabdomonadales (Euglenozoa). International Journal of Systematics and Evolutionary Microbiology 51:751-758.

PRINGSHEIM, E.G. 1948. Taxonomic problems in the Eugleninae. Biological Reviews and Biological Proceedings of the Cambridge Philosophycal Society 23:46-61.

SKVORTZOV, B.W. 1928. Die Euglenaceen Gattung Phacus Dujardin: eine systematich Ubersicht. Bericht der Deutschen Botanischen Gesellschaft 46:105-125.

STARMACH, K. 1983. Euglenophyta. In Flora Slodkowodna Polski, 3. (K. Starmach, ed.), Polska Academia Nauk, Warszawa.

TELL, G. \& CONFORTI, V.T.D. 1986. Euglenophyta pigmentadas de la Provincia del Chaco (Argentina). Nova Hedwigia 41:353-391.
TORGAN, L.C., MENEGHETTI, J.O. \& SILVA, S.M.A. 1979. Contribuição ao estudo do fitoplâncton do rio Caí, Rio Grande do Sul, Brasil. In Anais do XXX Congresso Nacional de Botânica. Sociedade Botânica do Brasil, São Paulo, p.141-150.

UHERKOVICH, G. \& SCHMIDT, G.W. 1974. Phytoplankton Taxa in dem zentralamazonischen Schwemmlandsee. Amazoniana 2:243-283.

WEIK, K.L. 1967. A revision of the genus Phacus Dujardin in Illinois. M.Sc. Thesis, University of Illinois, Illinois.

WETZEL, R.G. 1993. Limnologia. Fundação Calouste Gulbenkian, Lisboa.

WOŁOWSKI, K. 1998. Taxonomic and environmental studies on euglenophytes of the Kraków-Szestochowa Uppland (Southern Poland). Fragmenta Flora Geobotanica supl. 6:3-192.

XAVIER, M.B. 1989. O gênero Phacus Dujardin de lagos do Parque Estadual das Fontes do Ipiranga, São Paulo, Brasil. Hoehnea 16:149-164.

XAVIER, M.B. 1994. Criptógamos do Parque Estadual das Fontes do Ipiranga, São Paulo, SP. Algas, 5: Euglenophyceae (Euglenaceae pigmentada). Hoehnea 21:47-73. 